Celtic Myths in Cartoon Saloon's The Secret of Kells (2009) and Song of the Sea (2014): A Critique of Irish Postcolonial Animation

\title{
Marwa AlKhayat
}

Associate Professor, Faculty of Languages and Translation, Ahram Canadian University, Egypt.

\begin{abstract}
My study grows out of a desire to make sense of the attraction to Celtic myths as exemplified in The Secret of Kells (2009) and Song of the Sea (2014) since an academic breadth for the visual Celtic orientalism is still not fully achieved. To expand the scope of the Irish studies, the present paper is an attempt to construct the Irish criticism in the twenty-first century within the motion picture paradigm as manifested in the productions of the indigenous Irish studio, Cartoon Saloon, established in 1999 in Southeast Ireland. I argue for the equal significance of animation which has not been yet theorized in a comprehensive critical media discourse to emphasize Ireland's exceptional perception of itself as extraordinary. The premise of the study is to establish The Secret of Kells (2009) and Song of the Sea (2014) as Irish postcolonial animation to examine the tenor of the Celtic postcoloniality that has been shaped by energies of the past. The two animated films interrogate fanciful spatial practices undertaken by fictional child protagonists, Brendan, Ben and Saoirse to tackle fantasy as a genre to explore national symbols worthy of investigation within the postcolonial criticism, thereby, fantasy and animation are woven gorgeously to act as a critique. The child protagonists' epic journeys are remediated in animation to signify a metaphantasmagoric, metamedial enterprise to ardently explore Celtic myths. The two animated films depict Celtic myths in transmedia reflecting postmodern strategies of make-believing metafantasy critique to transgress the confines of the oral literature towards visual, acoustic, tactile, kinetic and digital new media regimes of representation. Cartoon Saloon is not in favor of computer imagery and instead it advocates the hand-drawn techniques which render animation its sleekness, round and curved lines to depict the exotic parallel worlds inhabited by mythic faeries. Finally, The Secret of Kells and Song of the Sea embody the features of performance forms in terms of dynamic visuals, distinctive Irish music and Celtic songs. Irish postcolonial animation maintains a medieval/timeless sense of immediacy within dream-like territories deploying 2D graphical design to draw the postmodern viewer into realms of Celtic myths and fantastical mise-enscène.
\end{abstract}

Keywords: Celtic Orientalism - Irish Aesthetic Animation - Postcolonial Studies - Cartoon Saloon Studio - Remediation 


\section{Introduction: Celtic Orientalism}

"Ireland is racially Celtic, linguistically Gaelic, religiously Catholic, politically Anglophonic and republican, organizational antinomian, sociology clannish, aesthetically zoomorphic and socially gregarious and alcoholic". (Johnston 247).

Irish studies, were traditionally, a well-accepted discipline of English studies, yet the literary contributions of Irish scholars and artists over a century mark "the evolution of Irish studies towards a separate and respectable discipline" (Gregor VII). Centuries ago, Ireland was recognized as a colony of the British Empire, however, during the decades of the twentieth century, Irish studies, as an autonomous academic discipline, have been established through a number of distinguished associations: the British Association of Irish Studies in 1985, the Spanish Association for Irish Studies in 2000, the European Federation of Associations and Centers of Irish Studies in 2013 and in Ireland itself the International Association for the Study of Irish Literatures in 1998 and the widespread attraction to the Irish studies "particularly noteworthy in the United States where the increase in the number of institutions offering courses in Irish Studies has been remarkable" (Bartlett et al 5).

Ireland's image of itself has been manifested in a plethora of themes that conveys its history and literature: The Catholic-Protestant Conflict, the Potato Famine, the EnglandNorthern Ireland struggle for independence, the Celtic Tiger economy as well as Ireland's problematic position as a former colony or as an ally of the British Empire. Academic postcolonial contributions such as David Lloyd's Anomalous States (1993) and Declan Kiberd's Inventing Ireland (1995) emphasize the uniqueness of the Irish studies inaugurating Irish criticism and orientalism. The two books function as a response to The Empire Writes Back (1989) that tackles the colonization of Ireland in a casual manner: "The Irish case very swiftly, perhaps, because the authors find these white Europeans too strange to justify their sustained attention" (Kiberd 5). Ireland has been portrayed "as a foil to set off English virtues, as a laboratory in which to conduct experiments and as a fantasy land in which to meet fairies and monsters" (2), yet the England-Ireland relation is considered as a reciprocal and a pivotal necessity: "If England had never existed, the Irish would have been rather lonely. Each nation badly needed the other for the purpose of defining itself" (2). Consequently, the 'Writing Back' paradigm is an endeavor to rewrite history from the perspective of the marginalized. Since the Celts were stigmatized by the "attributes of inferiority and subordination" (Bartlett et al. 47), the Irish culture has been associated with the medieval to 'reinvent' itself anew.

\subsection{Rationale and Scope}

My study grows out of a desire to make sense of the attraction to the Celtic myths as exemplified in The Secret of Kells (2009) and Song of the Sea (2014) since an academic breadth for the visual Celtic orientalism is still not fully achieved. To expand the scope of the Irish Studies, the current paper is an attempt to construct the Irish criticism in the twenty-first century within the motion picture paradigm as exemplified in the productions of the indigenous Irish studio, Cartoon Saloon, established in 1999 in Southeast Ireland. Ireland's Celtic mythologies reinforce an authentic Irish identity to enhance Neo-Celtic motion picture. The Celtic-Oriental association underscores the fact that the Irish are an oriental nation in terms of being at the edge of Europe with a secondary culture. Celticism and Orientalism have developed concurrently since medieval times and the Celtic revival as an aesthetic and a decolonizing strategy to smash the conceit of supremacy and race in the colonialist discourse. 
I argue for the equal significance of animation which has not been yet theorized in a comprehensive critical media discourse to emphasize Ireland's exceptional perception and image of itself as extraordinary to promote "world literary space" (304) - to use Pascale Casanova's expression - to offer an understanding of the meta-commentary on the Celtic heritage. It is an enterprise to move from the definition of 'Minor Literature' to that of World Literature within the framework of postcolonial studies. It is an act of literary recognition and autonomy to rebel against literary European hegemony.

The current study valorizes the idea of Irish postcolonial animation that vibrates with the Celtic spirit, geopolitical peripherality and racial difference that has not been established by skin color but by socio-political identifications to address a number of research questions: 1) What are the aesthetic features of Irish postcolonial animation? 2) Is animation art or craft or both? 3) What is the position of Irish postcolonial animation in the global marketplace? 4) How far has the Celtic orientalism nurtured the Irish postcolonial utopia? The premise of the study at hand is to establish The Secret of Kells (2009) and Song of the Sea (2014) as Irish postcolonial animated feature films to examine the tenor of Celtic postcoloniality that has been shaped by energies of the past. Celtic revival has been triumphal to turn a racial blemish of primitive child-like acts and backwardness into a positive, high caliber to endorse the study of the Celtic antiquity to positively reconstruct national identities.

\subsection{Cartoon Saloon: Indigenous Irish Studio}

The trio, Tomm Moore, Nora Twomey and Paul Young, have established Cartoon Saloon in Kilkenny to release animated feature films on Celtic mythologies and mysticism. The studio has succeeded in creating a charming visual spectacle of digital technology that exhibits a fusion of visual media and ancient myths, an amalgamation of Celtic and Christian motifs. In opposition to the 3D and CGI (Computer Generated Imagery) animation of Toy Story by PIXAR and Disney's studio, Moore advocates "artistically animated flatness" (Osmond 101) to emphasize the fluidity and distinct Celtic personality in animation that is primarily hand-drawn and painted backgrounds.

Film academic Paul Wells - in Animation: Genre and Authorship (2002) - remarks that the hand-drawn animation with stylized and intricate look in the global marketplace is an act of safeguarding the national art forms: "Many studios worldwide have insisted upon using their own indigenous fine arts traditions, mythologies and cultural imperatives in order to differentiate their own work from what may be regarded as a diluted form of American artistic and cultural imperialism" (2). It is an act to write back to the center to underscore realms of "internal consciousness rather than submit[ting] to a despised external setting" (Kiberd 118) to enhance a postcolonial myth fantasy in order to escape logocentric power. The fantastic logics function as a counter narrative to convey a timeless and hypothetical world of myths inhabited by extra mundane beings. Celtic myths, therefore, are both a structure and a concept to deepen cultural retrieval and to provide a critical space to exhibit the ways in which Irish studies can be a national epic.

Irish postcolonial animation offers a better possible world that exists within the fantasy consciousness, "but we are ideologically persuaded that the possible is actually the impossible" (Bloch 4). Irish postcolonial animation and Utopianism can enrich each other through energies of the past, a point discussed by Raffaella Bacconlini:

The utopian value of memory rests in nurturing a culture of memory and sustaining a theory of remembrance. These actions, therefore, become important elements of a political, utopian praxis of change, action, and empowerment: indeed, our reconstructions of the past shape our present and 
future. Memory, then, to be of use to Utopia, needs to dissociate itself from its traditional link to the metaphor of storage and identify itself as a process. As Utopia is a process, so memory needs to be perceived as a process, not fixed or reachable, but in progress (172).

The conceptual imagination of a better future through the synthesis of animation and myth is an act of re-appropriating the past to reinvent Celtic topographies of romantic nostalgia.

In his "Introduction" to The Routledge Companion to Postcolonial Studies (2007), John McLeod argues that postcolonial studies are involved in "a self-conscious process of contestation" which "secures a utopian ethics at heart"(8). The current study explores the association between the imagining of the Irish nation and the fertile utopian heritage which has been energized by the local cultural empowerment to renew the Irish Criticism:

Central the endeavor was the realization that the Irish had accepted London as the center of culture and civilization for too long and that the time had come for the Irish people to regenerate their own intellectual terms of references and narratives of cultural meaning ... [and] it is hardly surprising that the revival would eventually produce a movement which would take the self-help ethos to its most radical conclusion by advocating an alternative politics (Mathews 9).

Thus, it is the birth of the indigenous Cartoon Saloon Studio that furnishes the imagination of the Irish national identities. This rationale coheres with Valerie Fournier's notion of Utopianism which is "not a blueprint for a 'perfect society' but may be better conceptualized as a movement of hope. It undermines dominant understandings of what is possible and opens up new conceptual spaces for imagining and practicing possible of cultures ... it is about opening up vision of alternatives rather than closing down on a vision"(192). Irish postcolonial criticism has resurrected the utopian impulses within an indigenous animation as "for postcolonialists, the recovery of the memory of radical struggles in the past is an important element of any commitment to building contemporary modes of social consciousness" (Cleary 43). It is Kevin Whelan's term "radical memory" that deploys the past "to challenge the present, to restore into possibility historical moments that had been blocked or unfilled earlier" (60).

The two selected animated films are a reflection of the Celtic symbolism and Irish medieval monastic art. Celtic aesthetics are notable in terms of character configuration, setting design and mystic sensibilities that reject conventional realistic animation. Ireland is famed for mystic sentimentality and always hailed for being "the land of saints and scholars" (Connolly 79). This is well-exemplified in the 2009 Oscar-nominated The Secret of Kells which is set in medieval Ireland. It revolves around the Holy Book of Kells- in Trinity College library in Dublin - and Abbot Aiden's challenging mission to complete the illustrations of the beautiful manuscript that includes the Four Gospels of Mathew, Mark, Luke and John to tell the story of Jesus's life. The animated film is inspired by the Celtic iconography and insular art. The 2014 Oscar-nominated Song of the Sea is based on the ancient Celtic myth of selkie; half seal and half human. Ben and Saoirse are two children living with their father, Conor, who still suffers from the loss of his wife several years earlier.

The two animated films are emblems of a nation as an ideology and as an "imagined political community" (Anderson 6). This endorses the idea of a nation as a mutual sense of community imagined by the fellow-members, rituals, symbols and myths to stimulate a sense of belonging. Celtic distinctive myths are the focal points to establish the Irish national animation. Herein, memory functions within the utopian thought in a productive and dynamic way since the past is impetuous to fantasy in the political and cultural consciousness. Fantasy 
animation manipulates a plethora of textual devices as manifested in the selected animated films to create "a sense of vastness to replace the primary world, depicting a large number of [non-human] characters and complex plot lines, deploying cyclic plot structure and foregrounding a narrative frame that unites timeless mythic patterns with contemporary individual experience" (Fahmi 29).

\section{Irish Postcolonial Animation: An Aesthetic 'Remediation'}

"Animation is both art and craft; it is a process in which the cartoonist, illustrator, fine artist, screenwriter, musician, camera operator and motion picture director combine their skills to create a new breed of artist - the animator". (Blair 6).

The current study explores the Irish national identity through the moving image to examine the process of 'remediation' as proposed by Jay David Bolter and Richard Grusin in Remediation: New Media (1999): "In this last decade of the twentieth century, we are in an unusual position to appreciate remediation, because of the rapid development of new digital media" (5). 'Remediation' is the act of reproducing or remaking older artistic forms within the "twin logics of immediacy and hypermediacy"(5). These two contradictory tendencies share a complex, yet dependent relation since the two media forms oscillate between transparency and opacity. Immediacy transfers visual experiences in 3D animation to maintain the illusion of realism whereas hypermediacy draws attention to itself: "hypermediacy makes us aware of the medium or media and (in sometimes subtle and sometimes obvious ways) reminds us of our desire for immediacy" (34).

Within this rationale, The Secret of Kells and Song of the Sea are forms of a remediation of Celtic myths and symbols. The Secret of Kells is a remediation of the Holy Book of Kells, yet, it also illustrates the new story of Brendan; the young illuminator's adventure to the fantastic forest. Song of the Sea depicts the fantastic adventure of the last sealchild, Saoirse, and her brother through the Celtic mythology to find their way home to their father. As a seal, Saoirse has the magical power to free the cursed mythical beings with her singing rendering them back to the Spirit World. The two animated films are selected since they display shape-lifting and metamorphosis in order to be at the heart of the magical practices and to provide definite features of fairy tales. Fairy tales depicted in the two films function as portals to wondrous worlds to explore the "might be, could have been, perhaps will be" (Bruner 20). Both animated films, therefore, are based upon a performance strategy in which the construction of the fantastic environments becomes a priority in the film's production.

Animation offers an opportunity to experience visual virtual reality; graphics, bright colors, bland lightings and frame rates (Rheingold 46) - all seek to make animation transparent and the fascination with the practice of hypermediacy is evident in the heterogeneous style. Hypermediacy encourages the spectators to see something they could not otherwise see without the aid of mediation: it is "an immediacy that grows out of the frank acknowledgment of the medium" (Bolter \& Grusin 81). To approach Celtic myths, animation allows the modern viewer a doorway to a medieval visual reality through the remediation of different or alternate realms through animation technology. Irish postcolonial animation achieves a medieval sense of immediacy within dream-like realms deploying 2D graphical design to draw the modern viewer into the sphere of ancient myths. The modern spectators fluctuate between a sense of immediacy and an awareness of that sense since they experience "the same duality of looking at and looking through that is a feature of collage, photomontage, and modern art in general" (Bolter \& Grusin 155). 
To reach the global marketplace differently, Cartoon Saloon Studio rejects 3D graphics: "Disney was criticized as the one who destroyed the graphic freedom of animation in favor of live-action style realism, or the sly propagandist of American ideology, all over the world" (Bendazzi 107). Cartoon Saloon Studio's denunciation of CGI technology in favor of hand-drawn animation can enhance a non-linear reading of history as it is interrupted through the deployment of multiple temporalities within the construction of the animation: "fantasy, forgetfulness and the distortion of linear time thus built into memory narration, and form part of the viewers' experience, encouraging spectators to perceive memory as a transformative process rather than an accurate retrieval of the past" (Cook 7). The nationness as a notion is tackled by Homi Bhabha in Nation and Narration (1990) to create a sense of rupture and interruption to move from the linear historical model to a temporal dimension through the revival of Celtic legends and symbols to set an identification with a glorious past, thereby, the Irish nation becomes a narration in a dreamy atmosphere within an animation that is both immediate and hypermediated.

It is noteworthy that the interplay of Ireland [at the edge of Europe] and animation [on the fringe of Film Studies in academia] enhances notions of Irishness and nationalism within motion-picture paradigm. As a nation, Ireland is "a repository of mythic 'pre-modern' values and as the locus of cutting-edge developments in technology" (Connolly 79). Cartoon Saloon Studio is less commercial and far from simplifying or marauding historical accounts, yet it has achieved an immense success in the global box-office embarrassing 3D films with huge budgets.

\section{The Secret of Kells (2009): History or Fantasy?}

"We realized there was a sort of self-reflexive story in there about a kid who wanted to be an artist and was trying to preserve something that's quite difficult times, so we sort of felt, O.K., that kind of mirrors what we're trying to do with the hand-drawn animation". (Moore, "Interview" with RYZIK 2010; emphasis added).

Moore is inspired by the ancient crafts instead of being captured by the new CGI animation technologies. In this sense, The Secret of Kells is an expression of the immediacyhypermediacy dichotomy in which old artistic crafts are juxtaposed with new technologies. The Holy Book in Trinity College Library is an ancient manifestation of Aidan's "magical book" in the 2009 animated feature film: "The Book of Iona outshines all others because of the miracle of Coloumbkille's Third Eye" (Moore 2009):
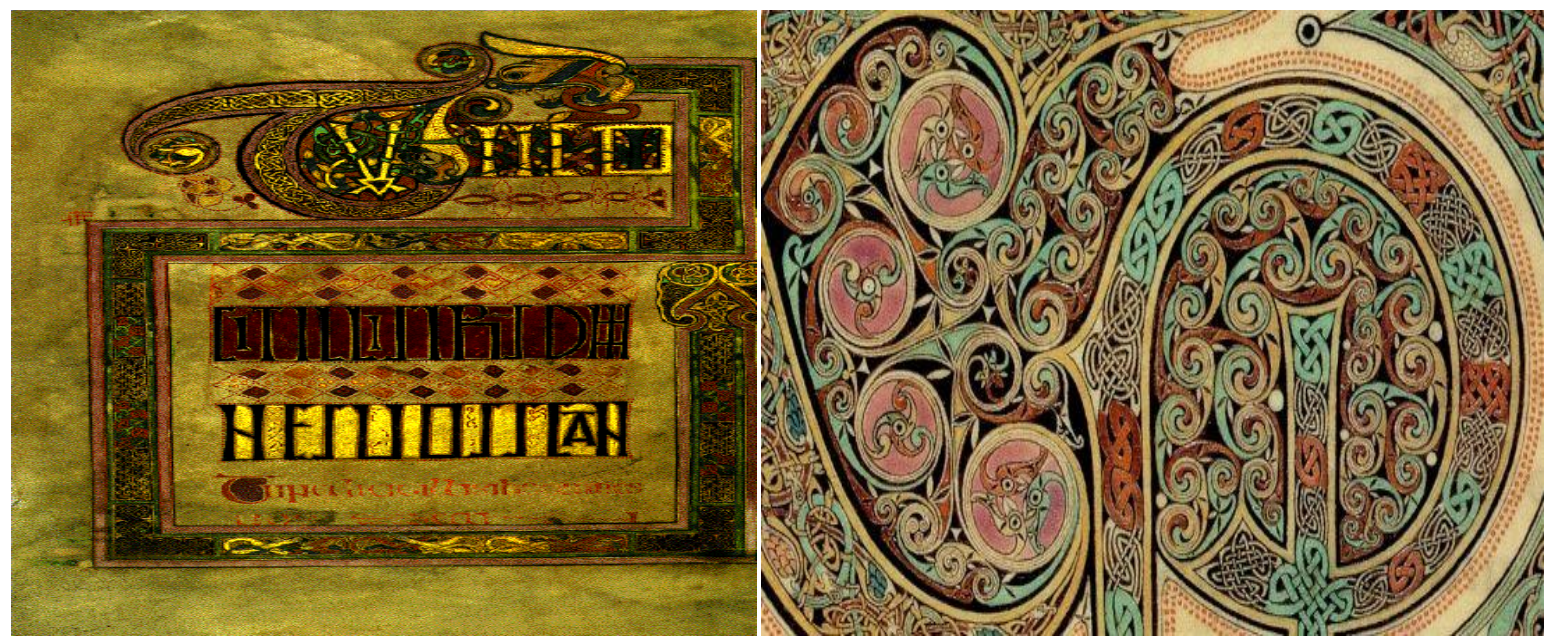

Figure 1: The Book of Kells in Trinity College Library 
Aidan's writings are extremely bright: "glow from the pages as though they are light. Sinners have been blinded while glancing upon the pages" (Moore 2009). The Secret of Kells is the modern counter part of the ninth century Book of Kells with its Christian iconography. The Book of Kells is a revered work of art with decorative letters in intricate Celtic designs, rich colors and a precious golden cover: "a medieval illuminated manuscript that ranks among the most important artefacts of Irish civilization. And it is only fitting that a movie concerned with the power and beauty of drawing - should be so gorgeously and intricately drawn" (Renshaw 2010). It is a timeless iconic Celtic book which is a reminiscent of Mandala art and today is regarded as "Ireland's finest national treasure" (Crisbacher 2017).

\subsection{A Philosophical Animated Tale: A Remediation of the Celtic Myth}

The Secret of Kells is about the fantastical story of how the Book of Kells has come to being. Although the beautiful manuscript remediates the holy Book of Kells, the animated film illustrates the new story of the young illuminator, Brendan. Leading a joyless life in the monastery, Brendan's Kells is under the raids of the Vikings who ferociously pursue gold. To escape his uncle's watchful eye, Brendan plays in the woods and he is captured by the illuminations of the beautiful manuscript made by the Irish monks. The key point is the interplay the Book of Kells and its medieval illuminations. Brendan's fascination with the insular art of the illuminations lures him to undergo a challenging task to get the "emerald green ink" from the woodland flora (Moore 2009). The adventurous journey is inspirational as Brendan fantasizes himself playing with the plant within the margins of the manuscript:

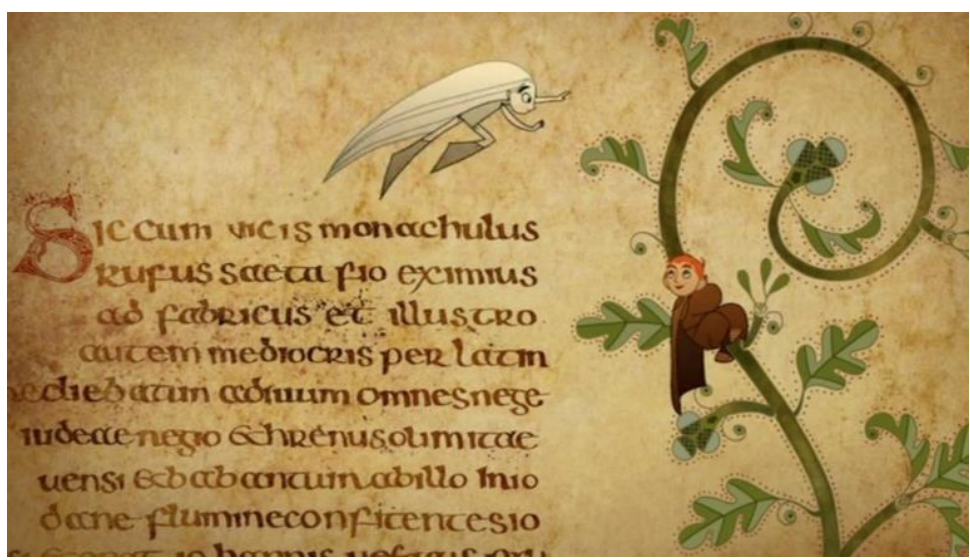

Figure 2: Brendan communes with the illustrated Natural Realm in Aidan's manuscript

Brendan defies the walled city to "unleash imagination" (Moore 2009). The adventure to the forest is a discovery of the powerful impetus of imagination and spirituality. The two orphans, Brendan and Aisling together achieve a sense of wholeness; one from the Christianized civilization and the other from the natural pagan fantasy realm. They complete each other; he explains the beauty of the Book of Kells and she teaches him how to climb trees. The Forest of Spirit calls him a "trespasser" (Moore 2009) and she functions as his anima to represent his intuitive side.

The dramatic significance of the forest fantasy lies in the dichotomy between matriarchal Paganism with patriarchal Catholicism. Abbot Cellach's outlook is rigid, strict and dogmatic that condemns playfulness, spirituality and mysticism. Abbot Cellach's animus representative of the rational side - stands in the way of achieving this sense of completeness or wholeness as I envisioned in the diagram below: 

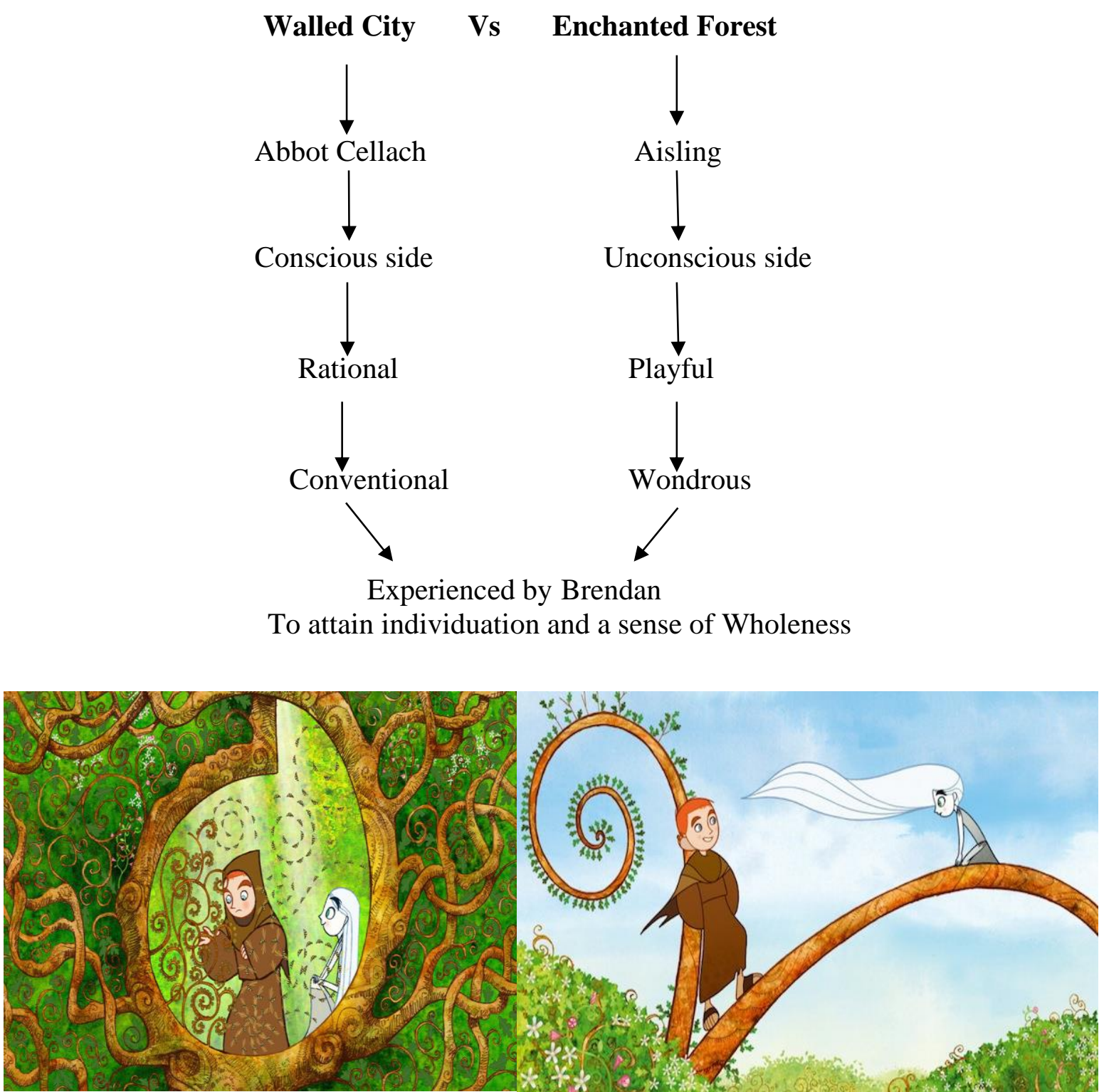

Figure 3: From the Walled City to the Enchanted Forest with the White Wolf/Girl

On the other hand, Brother Aidan of Iona is a signifier of an archetypal 'wise old mentor' who pushes Brendan to experience the lure, freedom and danger of the forest. The two Abbots are set in contrast to symbolize the dilemma of two choices: physical defense or spiritual knowledge. Cellach believes: "it is through the strength of our walls that others will come to trust the strength of our book" (Moore 2009) while Aidan claims that "people must have books so they may have hope" (Moore 2009). When the Vikings wage their barbarous attack, Brendan insists to save the green ink so as to save the nation's civilization; wall can be destroyed but books and faith can remain longer.

The remediated illustrations of the pagan book in the abstract, medieval art function as a comforting remedy to heal Cellach's sadness for losing Brendan after the Viking invasions. Therefore, both ancient artifacts and new technology can augment each other; to interpret the old art in terms of the new media and to interpret the new media in terms of the old art in a synergistic relationship: 


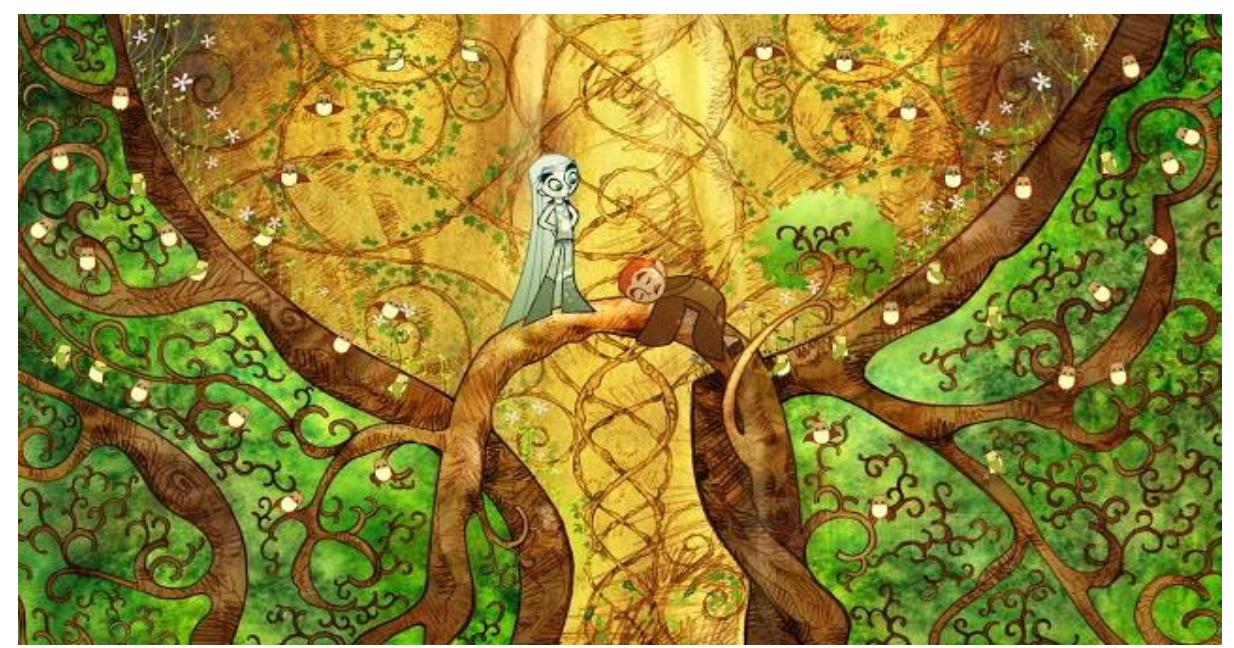

Figure 4: The Intricate Forest in Remediation of the Manuscript's Illustrations

Herein lies the vital strength of animation to remake the medieval art of the Book of Kells by imitating its artistic features in the modern animated images. Brendan is a fictional character, yet the Book of Kells does exist within a remediating relationship in which the newer and the older forms are "involved in a struggle for cultural recognition" (Bolter 14).

\subsection{Celtic Aesthetic Animation}

The Secret of Kells invokes the past for its style to tell a story in curves and swirls, rigid and soft lines, and in geometrical abstract shapes that are reminiscent of medieval art. The visual style weaves graphics with fluid and refreshing drawings "for being flat with false perspective and lots of colors" (Bendazzi 93) manifested in crispy lines, saturated colors, busy repeated patterns, endless Celtic knots, spirals, plaits, circles and arch panels to create complex ornaments. This intricate design evokes a sense of nostalgia of pre-Euro Irish style and it is incorporated in the motion picture in an attempt to imitate the Book of Kells to merge historical facts with imagination and legendary.

The animation style of contrasting lines and curves is manipulated to symbolize settings, characters and animals. Kells - the walled city - is rendered in a cubist-like perspective to illustrate the fact that Kells is an amalgamation of curves and lines:

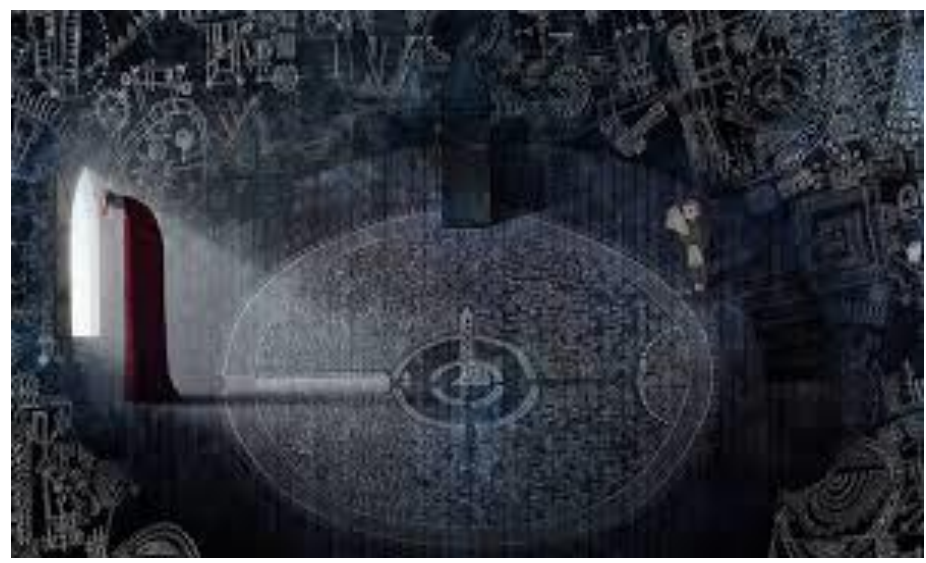

Figure 5: The Scriptorium

There are the angular central tower and the circular world that surrounds it. The houses as well as the scriptorium are half-spheres seen as semi-circles in the 2D cubist-like style. 
The depiction of the Northmen is in severe contrast to the villagers of Kells in the sense that the villagers are composed of curved lines and circular shapes whereas the Viking invaders are rendered in geometrical abstract faceless figures in square with sharp angular shoulders:

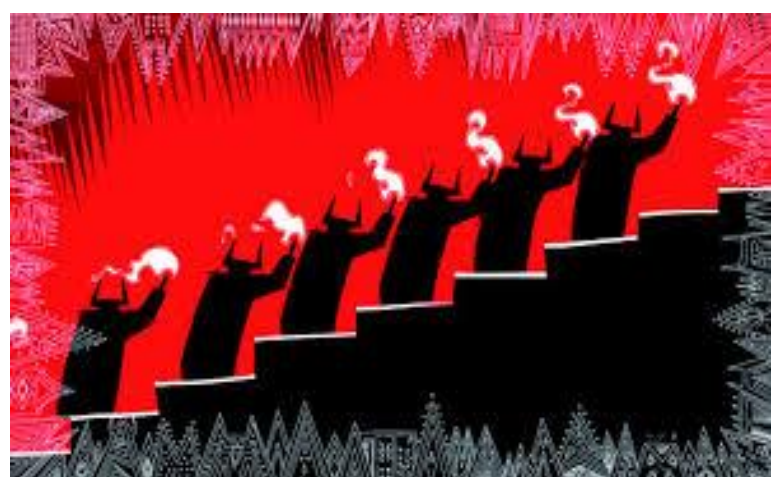

Figure 6: The Viking Invaders in Geometrical Shapes

The Viking hordes are illustrated as "shadowy blocks with rudimentary horns and glowing eyes, abstract figures of chaos" (Renshaw 2010) in frenzy red color attacking Kells savagely. The diversity of the villagers is juxtaposed with the uniformity and sameness of the Vikings. Brothers Assoua and Tang are completely different in appearance:

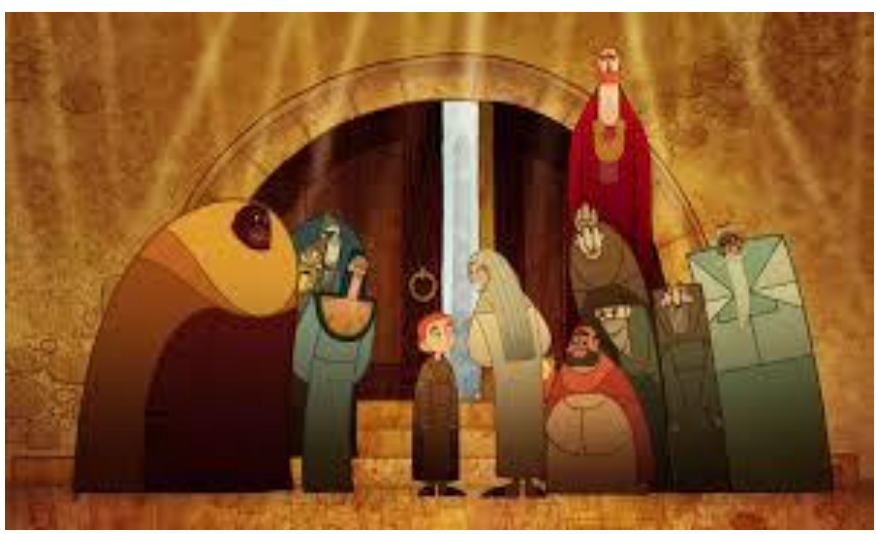

Figure 7: The Asian and African Illuminators

Both illuminators are rendered in curves; Assoua is huge and African whereas Tang is short, thin and Asian.

Abbot Aidan's ideology of spiritual knowledge is juxtaposed with Abbot Cellach's obsession with the construction of the wall as echoed in his colossal height in rigid lines:
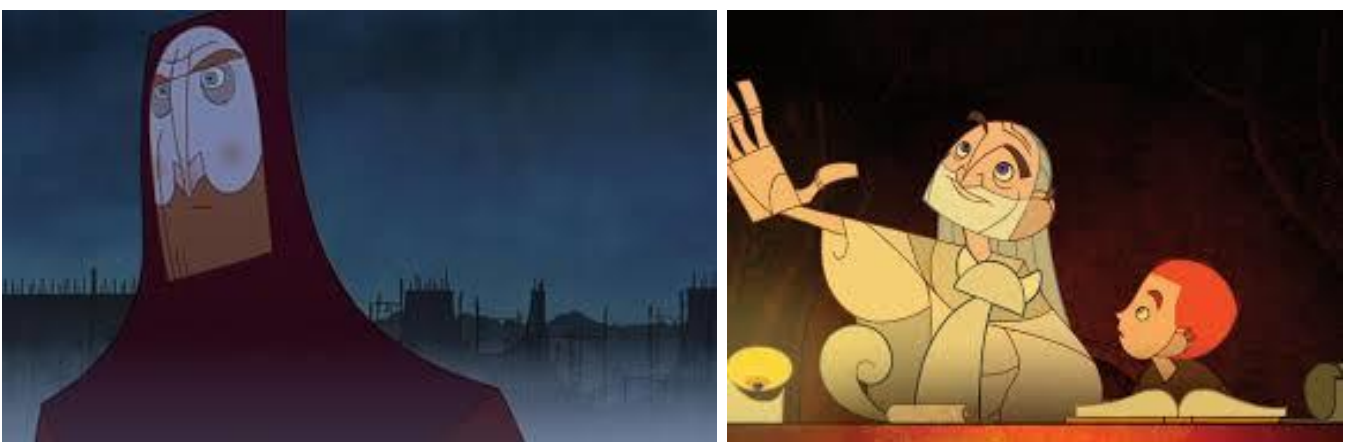

Figure 8: Cellach's rigid lines in contrast to Aidan's soft curved lines 
The finale renders him in softer curved lines to mark the shift of his point of view of the subtle power of the manuscript. Being no longer a foil character, he hails the symbolic meanings of the supremacy of knowledge, spirituality and mysticism that deconstruct notion of physical protection. Reunited happily, the adult Brendan displays to his dying uncle the complete Book of Kells and the film closes with the beautiful rendition of some illustrated pages.

The forest entrance evokes the ambiance of the ancient gothic cathedral. The forest is a hybrid of rounded surfaces and rigid lines as illustrated in its architectural structure:

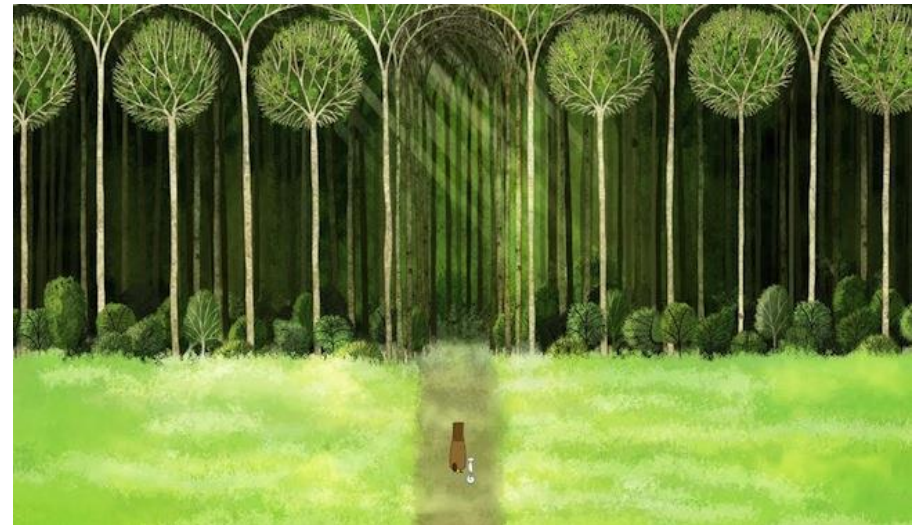

Figure 9: The Architectural Structure of Ancient Gothic Cathedral

This structural hybridity is emblematic of Brendan's feelings of curiosity and fear. As he becomes close to the Forest Spirit Aisling, the forest is seen made up of soft curves. In contrast, the dark menacing cave of the pagan god Crom Cruach is made up of statues and stone pillars with sharp corners.

Animals - in the enchanted forest - are symbolic significations of the eternal conflict between good and evil since they are depicted in either rounded or angular shapes to reflect different attitudes and sentiments. Brendan's initial encounter with the wolves is fearful since they attack him with their exaggerated teeth and pointed corner ears. However, Aisling herself - as a wolf girl - is in smooth rounded shape to convey her intimacy with the young illustrator. Crom Cruach is a huge snake-like creature in sharp angular form:
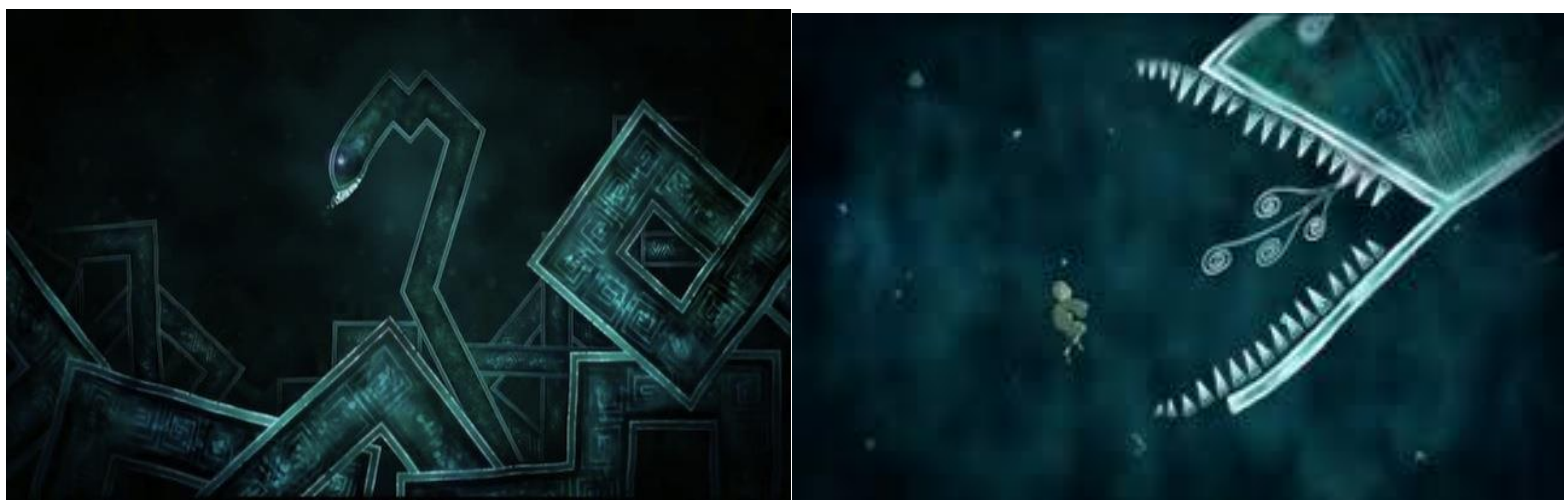

Figure 10: Crom Cruach: The Celtic Dark Deity of Death and Destruction

The angular snake consumes itself when Brendan blinds it to restore the crystal Eye of Colm Cille, a special magnifying lens to help Abbot Aidan complete his illustrations. The Celtic dark deity of death and destruction eats its tail and gets trapped in a never-ending square, ouroborous-like and on getting back to the forest victoriously, Brendan is surrounded by white flowers. 
Finally, the Book of Kells is inspirational and it wonderfully sets a relation between medieval art and modern animation. This creates a harmonious association between visualization and Natural world as well as between Christian civilization and mythic Paganism as dramatized in the remarkable relation between the two orphans, a Christian boy and a faery girl. The animation is amalgamations of imagination, historical facts and fantastical adventure knotted with Celtic myths, Christian iconography and insular art.

\section{Song of the Sea (2014): Fantastic Folklore as Remediation}

"Literature is the product of two impulses. There is the mimesis, felt as the desire to imitate, to describe events, people, and objects with such verisimilitude, the other can share your experiences, fantasy, the desire to change givens and alter reality - out of border, play, vision, longing or need for metaphoric images that will bypass the audience's verbal defenses". (Hume 20).

This quote triggers a significant inquiry about original myths and how far they can function as archetypes in the cultural memory. Folk myths are cosmic worldviews that underlie cultural consensus. The Oscar-nominated Song of the Sea is an animated hypothetical fiction that is deep-rooted in a timeless regional folklore with a wondrous flavor to depict a personal epic of the last seal child, Saoirse. The mythological selkies of Irish folklore are about the seal people who live as seals in the sea but become humans on land. Saoirse's epic mission is to recite an ancient song to free the selkies of Ireland from the curse which is the cause of their fading and disappearing.

Fantasy is "the literature of the impossible" (Fredericks 37). This world of the 'impossible' is "another order of reality from that in which we exist and form our notions of possibility" (Manlove 3). Remediation is an act of reframing seen as "the representation of one medium in another" (Bolter \& Grusin 45) when a new technology "appropriates the techniques, forms and social significance of other media and attempts to rival or refashion them in the name of the real" (Bolter \& Grusin 65). The present study seeks to interpret the inner logic of the fantastic world as a reimagined folkloric past.

Within this rationale, there are two "literary simulations of folkloric phenomena"; the first is to provide "verisimilitude and local color" and the second is to function as "models for production of folk-like materials" (Grobman 30). The audiences are taken into the parallel magical world of Irish mythologies since the animated film addresses both real and imaginary settings, real and mythical characters as well as Irish Celtic symbols. Ben and Saoirse discover how fairies live under the hump of the roundabout and they find out that owls are used by a witch to turn magical creatures into stones.

\subsection{Folk Animation}

The mythology of the Irish Selkie is remediated through animation to depict a dense action in an imaginary world. Thereby, animation involves projection and alterity to negotiate the creation of self-identity within the paradigm of virtual community: 


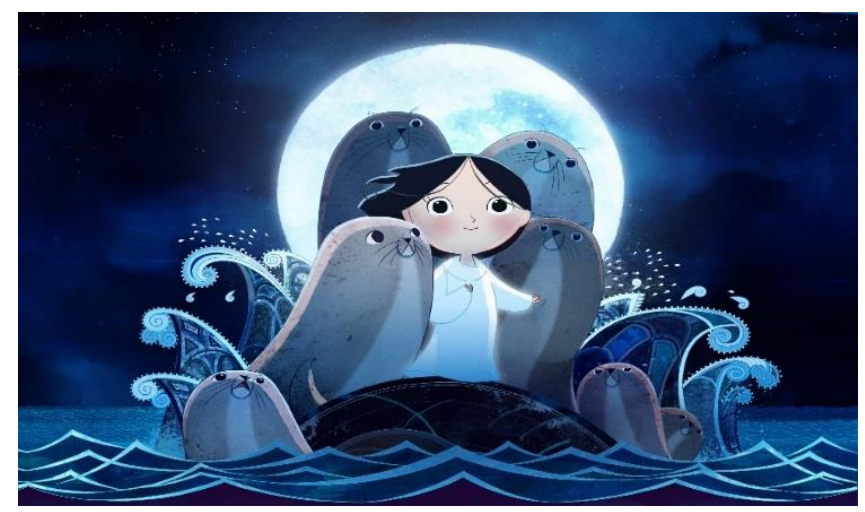

Figure 11: The Last Seal Child in all Ireland

Little Saoirse misrecognizes her external image which is seen as habitual and ordinary. Saoirse's difference is underlined; not only is she dumb and peculiarly dark-haired, but also a selkie. Animation - as a projection of human expression - enhances agency, inner will and strong personality outside the Self and into the fantastic world. Ben discovers that his sister is a selkie, a human who can transform herself into a seal like her mother, Bronagh. Ben's ethereal mother has entrusted him a musical conch shell telling about the Celtic songs which are later sung by Saoirse to face a curse that has inflicted the world of the Selkies.

In this sense, remediated animation focuses on the trope of multiple personalities or roles to interrogate the relationship between the Self and the external world. Little Saoirse valorizes ancient folklore through her Celtic songs to save the Irish Fae from the evil witch Macha's attempts to turn them into stones. Therefore, the journey to the fairyland signifies a metaphantasmagoric, metamedial undertaking to passionately explore the folk and cultural stakes of the Irish myths which themselves embody the imaginative experience of making sense of a mythical and timeless realm.

\subsection{Moore's Fantastic Aura within the 'Playful Transposition' of the Celtic Folklore}

"[Adaptation] is not a copy in any mode of reproduction, mechanical or otherwise. It is repetition but without replication, bringing together the comfort of ritual and recognition with the delight of surprise and novelty. As adaptation, it involves both memory and change, persistence and variation". (Hutcheon 173).

Moore's revisit of the Celtic myth of the sea creatures is a willful "playful transposition" (Ricoeur 87) to interpret the old oral narratives in terms of the modern 2D technology and to examine the poetics of animation in terms of mythical stories in a synergistic relationship. This act of adaptation always involves "both (re-)interpretation and (re-)creation" and this has been considered as an act of "appropriation" (Hutcheon 8) enhancing the animator's idiosyncratic perspective which is mythical and timeless underscoring the notion of 'willing suspension of disbelief'. The adaptation strategies of sea creature myth create a heterogeneous and fluid corpus.

In The Encyclopedia of Celtic Mythology and Folklore (2004), Patricia Monaghan refers to the narratological origin of selkie wives as enchanting shape-shifting creatures in the form of seals, but underneath their seal skins they have a human body (411) distinguished by dark hair and eyes. The mythical wives and earthy husbands struggle about the magical force of the seal skin. The skin's extraordinary ability embodies metaphorical significance shapeshifting transformation (Connor 36). The seal skin is a signifier of the borderline terrain between the animalistic, magical realm and the mundane, human world. The husband's stealing 
of the skin is a hopeless attempt to humanize and anthropomorphize the marvelous being since this struggle at taming the miraculous creature is a sheer failure.

Moore's story of the selkie wife marks her departure leaving behind her husband and two half-blood children, Saoirse and Ben. Moore states the influence of David Thomson's book People of the Sea (1954) which centers on the tradition of selkie folk, but as an Irish native he is also in communication with the orally transmitted folk tale tradition as revealed in the Online Irish News "Interview": "I was talking to a local lady, and we were disturbed by the fact that we were seeing these seals being killed on the beach", Moore recalls. The old lady from whom he rented the cottage told Moore that in ancient times the seals were respected in local beliefs since they were seen as selkies having the souls of the dead - the people who were lost at sea (Lee 2015). Moore articulates: "I realized that these were stories that we were losing - that connection to the landscape, that folklore, was dying out". He further explains: "I was hoping to make a film that reinvigorated the folklore for kids of my son's generation, and I thought an animated film would be an ambitious vehicle to do that with" (Lamble 2015). Song of The Sea's setting is drawn from the Dingle Peninsula landscape manifested in "the rolling hills, the dramatic, craggy rocks jutting out of the sea. It's a location that has attracted several filmmakers in the past" (Lamble 2015). Song of The Sea's exceptional scenery underscores a fantastical, child's-eye outlook of south-west Ireland where rocks come to life, faeries live underneath roundabouts and the agitating seas are inhabited by charming beings.

Song of the Sea illustrates the influence of Miyazaki's Japanese anime Spirited Away (2001) within an enterprise of "plural stereophony of echoes, citation, references" (Barthes 160) to create a fluid animation. Both Miyazaki - "Walt Disney of Japan" (MacWilliams 48) and Moore are postmodern performers/animators for not favoring Disney Studio and the hyperstylized computer generated imagery of PIXAR as well as in their genuine endeavors to reconfigure ancient national symbols and myths in meta-fantasy realms:

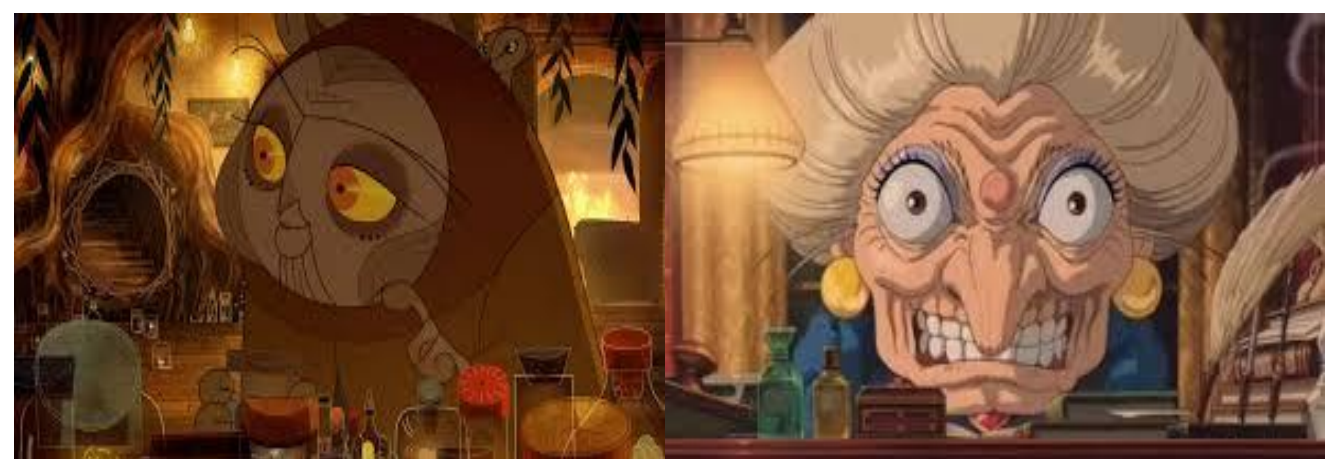

Figure 12: The Owl Witch in Song of the Sea looks like Yubaba in Spirited Away

The act of appropriation explores "the cultural and aesthetic politics behind the impulse to adapt" (Sanders i). The lexis of adaptation is highly labile: "variation, version, interpretation, imitation, proximation, supplement, increment, improvisation, prequel, sequel, continuation, addition, paratext, hypertext, palimpsest, graft, rewriting, reworking, refashioning, re-vision, re-evaluation" (3). Moore explains in many interviews that he has always been intrigued by films such as the work of Hayao Miyazaki, that offer an insight into an unfamiliar culture while communicating universal themes" (Hadfield 2016). Within the Kristevan model, animation is a living dynamic mosaic of codes and sign-systems, thereby, Song of the Sea acts as "parasitical presences, echoes, allusions, guests, ghosts of previous texts" (Gilbert and Gubar 46): 


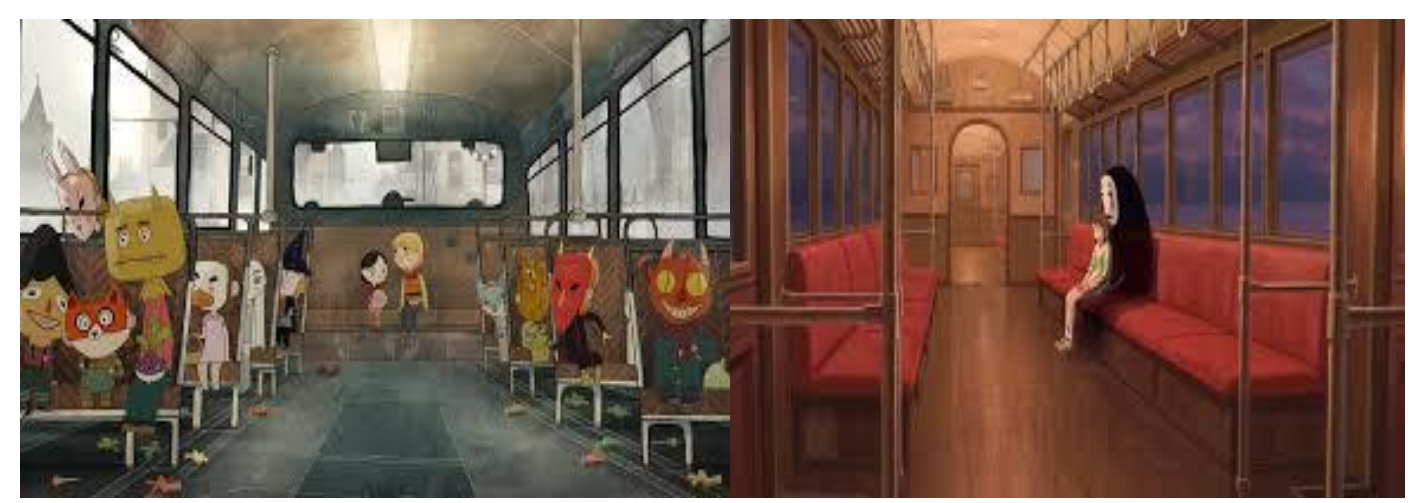

Figure 13: Song of the Sea as a Textual Ghost

Celtic symbolism is fused with the Eastern artistry of Orientalism to produce the distinctly exceptional aesthetics of Song of the Sea. This reveals how animation is made by animation to evaluate the 'literariness' of intertextual reference. Affinity is set between the Bus Scene in the Song of sea and the Train Scene in Spirited Away. This media reference is the reproductive impulse of appropriation to analyze how motion picture feeds off and creates other ones. This performance of re-vision highlights the act of looking back to create a heterogeneous animation or a "Celtic Miyazaki-esque" (Noisewar Internetlainen 2015) flat-footed animation.

Song of the Sea fulfills Hutcheon's definition of adaptation: it is an "announced transposition of a particular work or works" (6); it involves a shift in the medium - a transition from the oral literature to the screen. The few lines at the very beginning of the film ("Come away, O human child! /To the waters and the wild/With a faery, hand in hand, /For the world's more full of weeping than you can understand") are the refrain from "The Stolen Child". Textual hauntings are metaphorically the act of rewriting impulse as manifested in Yeasts's poem "The Stolen Child". As a visionary nationalist, Yeasts invokes the Celtic metaphors to return to a time where Ireland was one nation. Stanza one depicts the setting of the faeries who lure the child to go away with them to the enchanting land of the faeries. Only the faeries and the child can maintain freedom and innocence as manifested in the extended water imagery which is a signifier of free flowing life.

The audience enters by the end of this poetic quote the realm of fanciful animation to hear a Celtic song sung beautifully by a selkie woman: "between the here, between the now" (Moore 2014). The trope of 'replaying' oral literature is intermingled with music, songs and ritual dances. It also collides with the concept of 'here-and-now' through "flashbacks and flashforwards" (Hutcheon 63) to evoke a sense of presence and immediacy to interrelate the past, the present and the future through the visual and aural immediacy of performance. Herein lies the appeal of adaptation since the animated film has increased the delight of mythical stories to enjoy the mixture of familiarity and novelty. What is intriguing is that adaptation fulfills the desire of familiarity and novelty since the viewer in every present instance is wavering "between the replica and the invention, between the desire to return to the known pattern, and the desire to escape it by a new variation" (Kubler 72). This act of repetition reinforces cultural representation and enhances the power of indigenous myths and symbols.

\subsection{Animated Folkloric Leitmotifs: An Interplay of Natural and Human Worlds}

"There is something important in the folklore, in the stories that link people to their environment and where they're from that's worth remembering. You lose a lot more than just stories when you lose folklore". (Moore, "Interview" with Keegan 2015). 
The association between the Natural world and the Human world is manifested in the amalgamation of both worlds in surreal visuals depicting Ben in their centers:

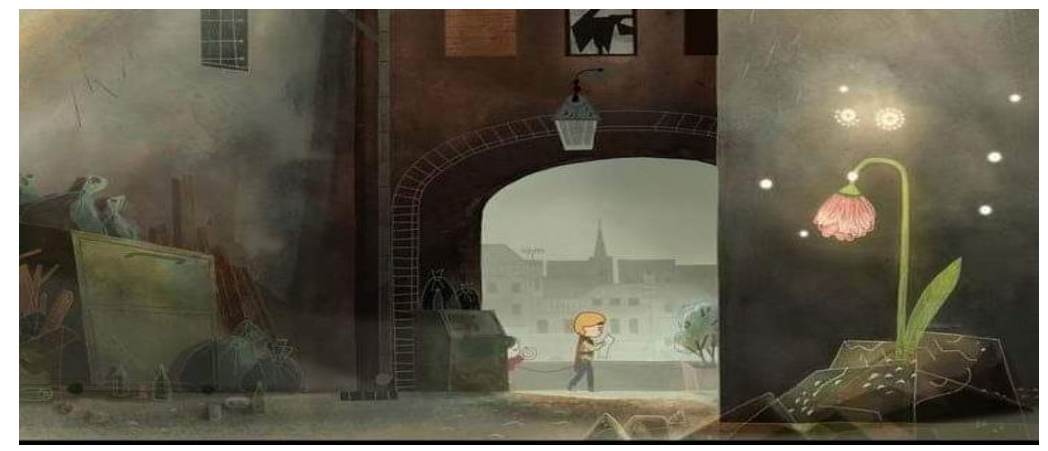

Figure 14: The Duality of Real and Magical Worlds

The vivacity of the flower is juxtaposed with the grey tones of the city to highlight the vibrancy of magic in contrast to the muteness of the city. This underlies the concept of the "sacred landscape" (Hicks 40) to signify the celebration of folkloric countryside since the animation centers on the lives of selkies to honor and respect them. The stone faeries are illustrated to speak of the sacredness of the mythic landscape:

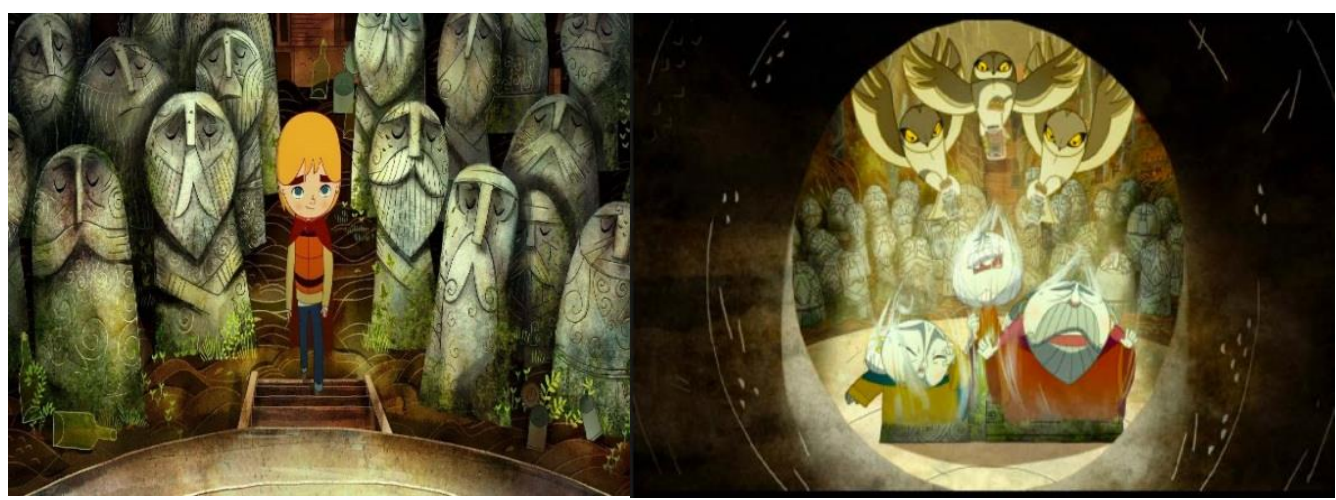

Figure 15: The Stone Faeries as Remediation of the Celtic Rock Art

It is noteworthy that the stone faeries have "spirals, arcs, and zigzag motifs which are characteristic of both Irish passage tombs and rock art of the Neolithic period" (O'Kelly 94):
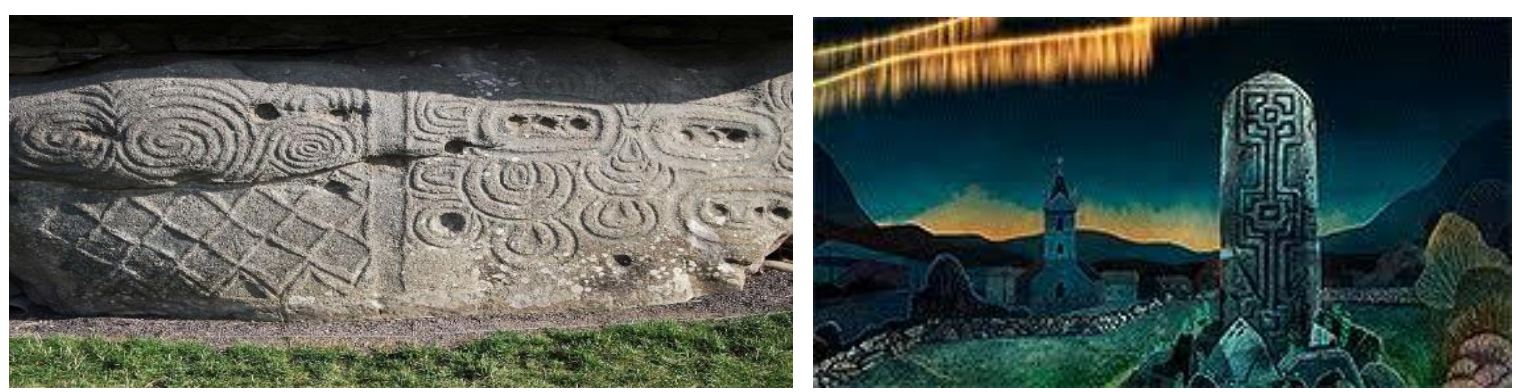

Figure 16: The Kerbstone Rock at Newgrange in County Meath, Ireland dates to $5^{\text {th }}$ century is remediated in the 2014 animated film

Spiral patterns become a motif integrated in the film's composition to reinforce the power of Celtic myths and symbols: 


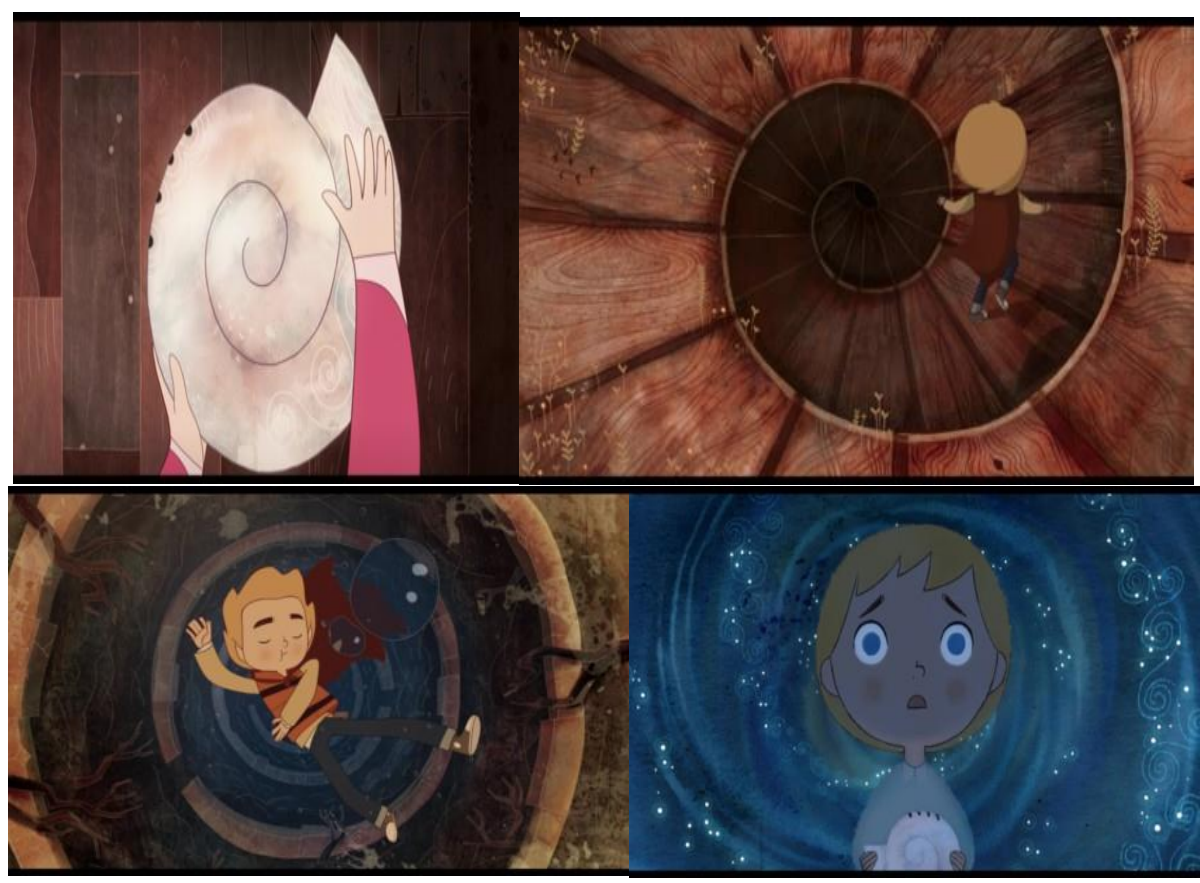

Figure 17: Magical Spirals

These visuals act as "transmutation or transcoding" (Hutcheon 16) in the sense of being recoded into a new set of filmic mirroring. In other words, remediation occurs in the form of intersemiotic transposition from one sign system to another.

Celtic spirals are set on the stone statues and there is also a feather carving on the wall behind the characters used to be worn by pagan Irish singers:

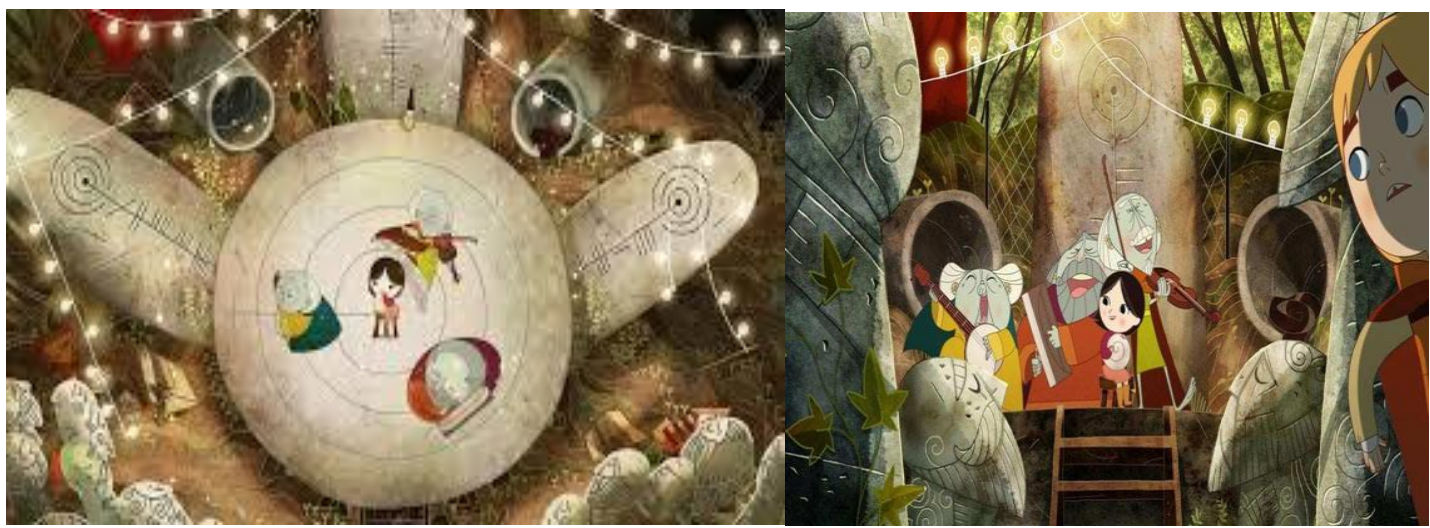

Figure 18: Saoirse and the Fae Folk within their Roundabout Haven

Thereby, adaptation is both "a product (as transcoding) and a process (as creative reinterpretation)" (Hutcheon 22) manifested in the showing mode that immerses the viewer interactively through the perception of the aural, visual and gestural representations in a rich mise-en-scène that is full of excitement and revelation.

Moreover, Ben's encounter with the Great Seanchaí is overwhelmed by Celtic knitting spirals to evoke folkloric Irish tradition. A Seanachai is a storyteller in Celtic myths that have passed from the old generations on to the next ones. The Great Seanchaí keeps all the folk stories in his long hair in order not to forget them and to retell many times to future generations. In so doing, animation redefines "the material world and captures the oscillation between interior and exterior states, thus engaging with matters both of (aesthetic, spiritual and 
intellectual) consciousness and the reception of a pragmatic (socio-cultural) 'reality'" (Wells, Animation and America 7).

The human characters have mythic counterparts serving as a bridge between the natural and earthy worlds. In Dictionary of Celtic Mythology (1994), Peter Ellis states that Mac Lir is the "sea deity" whose name means "the son of the sea" (285) and he is also the governor of Tír Tairngire, the Land of Promise and the Isle of Man (Spaan 176) since his giant body is illustrated in the film as a stone in the form of an island:
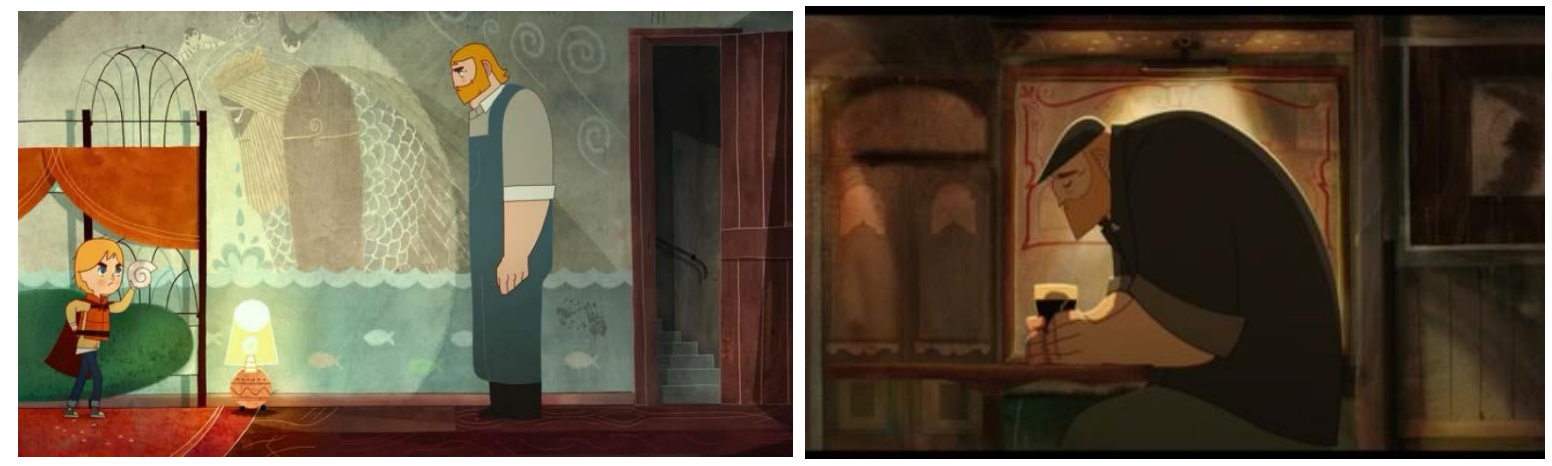

Figure 19: Mac Lir in the background in the form of a stone concretizes symbolically the human character Conor

The stylistic quality of the mise-en-scène interacts to craft "the overall composition in which characters do not exist within a setting but rather from visual elements that merge with the setting" (Brodwell \& Thompson 113). Mac Lir - as a stone island to symbolically reflect Conor's inner mental suffering - creates an aesthetic harmony to comprehend Conor's dismal physical posture drawing the scene closer towards abstraction and metaphoric mise-en-scène.

Wells illuminates that it is desirable to "embrace the artifice and illusionism of animation, so that you are able to create 'plays within plays' or 'films within films' to condense your plot, but more importantly, to 'illuminate' a supposedly-known or taken-for-granted world, from a different perspective" (2006: 33). On the one hand, an affinity is drawn between the Owl Witch Macha - known in the Irish folk belief as "a presage of death" (Hógáin 57) and Mac Lir's mother. On the other hand, Granny looks like the Owl sharing the same facial features and expressions:

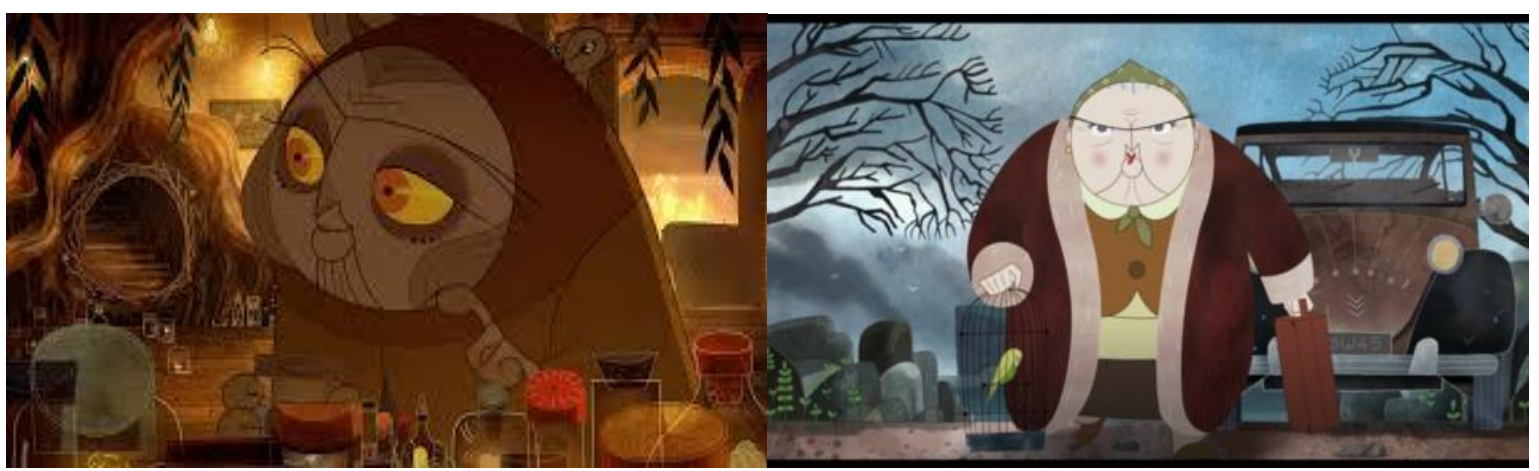

Figure 20: The Macha and Granny Affinity

Mac Lir has been turned into an emotionless stone while Conor has sent the two children to live with their city-dwelling grandmother. Granny steals the magic white fur coat from the selkie girl to deprive her of the supernatural gifts, an act that initiates the central conflict in the events. 
Finally, remediation acts as a pivotal cultural memory since "the archives of cultural memory consist not only of the stories, images, or documents of the past but also of the 'act of transfer' without which we would have no access to them" (Hirsch \& Smith 9). Sea creatures' fairy tales function as a cultural treasury of archetypal characters and storylines. Thereby, these fairy tales possess a peculiar set of signifiers that can be investigated in their own right. Tones of nostalgia are visually and acoustically displayed to pay homage to the sublime Nature. The music of the film is an expression of Gaelic lyrics and the soundtracks are achieved through the cooperation between "composer Bruno Coulais and the Irish folk band Kila" (Debruge 2014) to glorify the Celtic songs within a modern zest manifested in a significantly handcrafted touch with rich watercolor backgrounds full of visual vitality.

\section{Conclusion}

Irish postcolonial animation has emerged globally with an outstanding success to rival the animation produced by Disney empire. Tomm Moore's animated films offer a better perception of how Irish postcolonial animation has brought about pivotal changes in the way the West perceives Irishness. The two animated films examine fanciful spatial practices undertaken by fictional child protagonists, Brendan, Ben and Saoirse, to tackle fantasy as a genre not intended to express frivolous escapism, but to explore national symbols worthy of investigation within the postcolonial criticism, thereby, fantasy and animation are woven gorgeously to act as a critique.

The child protagonists' epic journeys are remediated in animation to signify a metaphantasmagoric, metamedial enterprise to ardently explore the Celtic myths. The two animated films depict Celtic myths in transmedia reflecting postmodern strategies of makebelieving metafantasy critique to transgress the confines of the oral literature towards visual, acoustic, tactile, kinetic and digital new media regimes of representation. Moore is not fond of computer imagery, instead, he favors the hand-drawn techniques which offer animation its sleekness, round and curved lines to depict the exotic parallel worlds inhabited by mythic faeries.

The link between the two animated films is the ability to hold connotation between fantasy and reality. The ideological uniqueness of the two films is the opposition to Disney in the sense that they acknowledge heterogeneity as a cultural alternative to American homogenization. Finally, The Secret of Kells and Song of the Sea embody the features of performance forms in terms of dynamic visuals, distinctive Irish music and Celtic songs. Irish postcolonial animation maintains a medieval/timeless sense of immediacy with dream-like territories deploying 2D graphical design to draw the viewer into postmodern realms of Celtic myths and fantastical mise-en-scène.

\section{Works Cited}

Anderson, Benedict. Imagined Communities, London: Verso, 1991.

Baccolini, Raffaella. "Finding Utopia in Dystopia: Feminism, Memory, Nostalgia, and Hope", Utopia Method Vision: The Use Value of Social Dreaming, Tom Moylan and Raffaella Baccolini (eds), Bern: Peter Lang, 2007, pp. 159-89.

Barrier, Michael. Hollywood Cartoons: American Animation in its Golden Age. Oxford: Oxford University Press, 1999.

Bartlett, Thomas, et al. Irish Studies: A General Introduction. Dublin: Gill \& Macmillan, 1988. 
Barthes, Roland. Image-Music-Text. (Trans.) S. Heath. New York: Hill \& Wang, 1977.

Barton, Ruth. Irish National Cinema. London: Routledge, 2004.

Bendazzi, Giannalberto. Animation: A World History: Volume III: Contemporary Times. Florida: CRC Press, 2015.

Bhabha, Homi. Nation and Narration. London \& New York: Routledge, 1990.

Blair, Preston. Cartoon Animation. California: Walter Foster, 1994.

Bloch, Ernst. The Utopian Function of Art and Literature: Selected Essays, trans. Jack Zipes and Frank

Mecklenberg, Minneapolis: University of Minnesota Press, 1989.

Bolter, Jay. "Transference and Transparency: Digital Technology and the Remediation of Cinema". Intermédialités 6, 2005, pp.13-26.

Bolter, Jay, and Richard Grusin. Remediation: Understanding New Media. Cambridge \& Massachusetts: The MIT Press,1999.

Bordwell, D., and K. Thompson. Film Art: An Introduction. New York: McGraw Hill, 2008.

Bruner, Jerome. Making Stories: Law, Literature, Life. New York: Farrar, Straus \& Giroux, 2002.

Casanova, Pascale. The World Republic of Letters. Trans. M. B. Debevoise. Cambridge: Harvard University Press, 2005.

Cleary, Joe. "Amongst Empires: A Short History of Ireland and Empire Studies in International Context", Eire-Ireland 42.1 and 42.2, 2007, pp. 11-57.

Collin, Robert. "Song of the Sea: The Deepest Animation You'll See All Year". Interview with Tomm Moore, 12 July 2015. https://www.telegraph.co.uk/film/song-of-the-sea/tommmoore-making- of-interview/

Connolly, Maeve. "Theorising Irish Animation: Heritage, Enterprise and Critical Practice". National Cinema and Beyond: Studies in Irish Film, $2^{\text {nd }}$ edition. John Hill and Kevin Rockett (eds.). Dublin: Four Courts Press, 2005, pp 79-89.

Connor, Steven. The Book of Skin. London: Reaktion Books, 2004.

Cook, Pam. Screening the Past: Memory and Nostalgia in Cinema. Oxford: Routledge, 2005.

Crisbacher, Deanna. "World Animation: Ireland - The Secret of Kells". March 30, 2017. http://deanna-crisbacher.blogspot.com/2017/03/world-animation-ireland-secret-ofkells.html

Debruge, Peter. "Film Review: 'Song of the Sea'". Variety. September 21, 2014.

Ellis, Peter Berresford. Dictionary of Celtic Mythology. New York: Oxford University Press, 1994.

Fahmi, Marwa. "Fantasy Chronotope in Two Animated Children's Films: Walt Disney's Alice in Wonderland (1951) and Hayao Miyazaki's Spirited Away (2001)". Studies in

Literature and Language, 14 (1), 2017, pp. 28-38. 
http://www.cscanada.net/index.php/sll/article/view/9120,

DOI: http://dx.doi.org/10.3968/9120

Fredericks, S. C. "Problems of Fantasy". Science Fiction Studies, 5 March, pp. 20-37, 1978. https://www.depauw.edu/sfs/backissues/14/fredericks14art.htm.

Fournier, Valerie. "Utopianism and the Cultivation of Possibilities: Grassroots Movements of Hope", Utopia and Organization, Martin Parker (ed.), Oxford: Blackwell, 2002, pp. 189-216.

Gilbert, Sandra M., and Susan Gubar. The Madwoman in the Attic: The Woman Writer and the Nineteenth-Century Literary Imagination $2^{\text {nd }}$ edition, New Haven: Yale University Press, 2000 (1979).

Gregor, Kath (ed.). International Journal of English Studies. Murcia: Universidad de Murcia, 2002.

Grobman, Neil. "A Schema for the Study of the Sources and Literary Simulations of Folkloric Phenomena". Southern Folklore Quarterly, 43: 1979, pp. 17-37.

Hadfield, James. "Song of the Sea: Seals, Fairies and Ancient Folk". https://www.japantimes.co.jp/culture/2016/08/17/films/film-reviews/song-sea-sealsfairies- ancient-folk-songs/, August 17, 2016.

Hicks, Ronald. "The Sacred Landscapes of Ancient Ireland". Archaeology. May \& June 2011, pp. 40-45.

Hirsch, Marianne, and Valerie Smith. "Feminism and Cultural Memory: An Introduction". Signs: Journal of Women in Culture and Society, 26 (11), pp. 141-170, 2002.

Hógáin, Dáithí Ó. "Dreaming and Dancing: W. B. Yeats's Use of Traditional Motifs in "The Dreaming of the Bones (1919)". Hungarian Journal of English and American Studies. vol. 8, no. 1 (Spring 2002), pp. 57-75.

Hume, Kathryn. Fantasy and Mimesis. New York: Methuen, 1984.

Hutcheon, Linda. A Theory of Adaptation. $2^{\text {nd }}$ edition, London \& New York: Routledge, 2006.

Johnston, Dillon. Irish Poetry After Joyce. Syracuse: Syracuse University Press, 1997.

Keegan, Rebecca. "Animator Tomm Moore lives the dream with a 'Song' in his heart", "Interview", Los Angeles Times. January 09, 2015.

Kiberd, Declan. Inventing Ireland: The Literature of the Modern Nation. London: Vintage, 1995.

Kubler, George. The Shape of Time: Remarks on the History of Things. New Haven: Yale University Press, 1962.

Lamble, Ryan. "Song of The Sea: How an Animated Treat was Made". July, 2015, https://www.denofgeek.com/movies/song-of-the-sea/36038/song-of-the-sea-how-ananimated-treat-was-made.

Lee, Jenny. "Newry Animator Making a Gig Splash in Movie World". Online "Interview" with Tomm Moore, June 2015, https://www.irishnews.com/lifestyle/2015/06/30/news/newry-animator- making-abigsplash-in-movie-world-151712/ 
Lloyd, David. Anomalous States: Irish Writing and the Post-Colonial Moment. Dublin: Lilliput, 1993.

MacWilliams, M. W. (2008). Japanese Visual Culture: Explorations in the World of Manga and Anime Armonk; NY\& London: M. E. Sharpe Press.

Manlove, Colin. Modern Fantasy: Five Studies. Cambridge: Cambridge University Press, 1975.

Mathews, P.J., 'The Irish Revival: A Re-appraisal', New Voices in Irish Criticism, Mathews, P.J. (ed.), Dublin: Four Courts Press, 2000.

McLeod, John. "Introduction", The Routledge Companion to Postcolonial Studies, John McLeod (ed.), London: Routledge, 2007, pp. 1-18.

Milligan, Mercedes. "Cartoon Saloon's Secret is Out". Animation Magazine, Dec. 2009-Jan. 2010.

Monaghan, Patricia. The Encyclopedia of Celtic Mythology and Folklore. New York: Facts on File, Inc., 2004.

Moore, Tomm. Cartoon Saloon - Irish Animation Studio. http://www.cartoonsaloon.ie/, http://www.cartoonsaloon.ie/work/song-of-the-sea/, 2019.

Noisewar Internetlainen. "Analysis of Song of the Sea: Salvation by Folklore". March 24, 2015. http://warandnoise.com/analysis-of-song-of-the-salvation-by-folkore/

O'Kelly, M.J. "Neolithic Ireland: A New History of Ireland". Vol. I Prehistoric and Early Ireland. Oxford: Oxford University Press, 2005, pp 94-96.

Osmond, Andrew. 100 Animated Feature Films. London: Palgrave Macmillan, 2010.

Renshaw, Scott. "Illumination Building: The Secret of Kells Gives Irish History Beautifully Distinct Animation". April 28, 2010. https://www.cityweekly.net/utah/the-secret-ofkells/Content?oid=2145294

Ricoeur, Paul. "Appropriation". A Rioceur Reader, Mario Valdes (ed.). London: Harvester Wheatsheaf, 1991.

Rheingold, Howard. Virtual Reality. New York: Simon \& Schuster, 1991.

RYZIK, Melena. "An Indie Takes on Animation's Big Boys". The New York Times, 13 March, 2010.

Sanders, Julie. Adaptation and Appropriation: The New Critical Idiom. London \& New York: Routledge, 2006.

Solomon, Charles. The History of Animation: Enchanted Drawings. New York: Wings Books, 1994.

Spaan, David B. "The Place of Manannan Mac Lir in Irish Mythology". Folklore 68, No. 1 (Autumn 1965): pp. 176-195.

The Book of Kells. London and New York: Global Grey Ebooks, 2018, Originally 1920, described by Sir Edward, https://www.globalgreyebooks.com/book-of-kellsebook.html 
Thill, Scott. "Tomm Moore on 'Song of the Sea' Reinventing 2D, and Dodging the Studio System". Cartoon brew 2 Jan. 2015.

Thomson, David. The People of the Sea: A Journey in Search of the Seal Legend. London: Turnstile Press, 2000 (orig. 1954).

Wells, Paul. Animation: Genre and Authorship. London: Wallflower Press, 2002.

Animation and America. Edinburgh: Edinburgh University Press, 2002.

The Fundamentals of Animation. Lausanne, Switzerland: Bloomsbury Publishing PLC, 2006.

Whelan, Kevin. "The Memories of "The Dead", The Yale Journal of Criticism 15.1, 2002, pp. 59-97.

Yeats, W. B. "The Stolen Child." In The Wanderings of Oisin and Other Poems. London: Kegan Paul \& Co, 1889.

\section{FILMOGRAPHY}

Moore, Tomm, and Nora Twomey dir. The Secret of Kells. Cartoon Saloon, 2009.

Moore, Tomm dir. Song of the Sea. Cartoon Saloon, 2014. 